\section{CALL FOR NOMINATIONS}

\section{Hewlett-Packard Europhysics Prize}

The Selection Committee for the Hewlett-Packard Europhysics Prize invites nominations for the 1992 award. The prize is given for an outstanding contribution to condensed matter physics within the previous five years, with the potential for leading to advances in the fields of electronic, electrical or materials engineering. Nominations may be submitted by EPS members as individuals or as representatives of a Division or Section.

The Hewlett-Packard Europhysics Prize has been awarded to the following:

1983: I. Silvera

1984: G. Binnig, H. Rohrer

1985: J. Als-Nielsen, M. Pepper

1986: F. Mezei

1987: I. Yanson

1988: J.G. Bednorz, K.A. Müller 1989: F. Steglich, H.-R. Ott,
G. Lonzarich

1990: R. Car, M. Parrinello

1991: D. Jérome, K. Bechgaard

To maintain the extremely high standard, it is necessary that the Committee receive proposals which represent the breadth and strength of European condensed matter physics. It is also important that the submitted nominations be complete. They should comprise at least:

- a detailed motivation for the award, including a clear definition of the work and its significance;

- a brief curriculum vitae of the nominee;

- a list of relevant publications.

It is also extremely helpful it we receive letters of support from authorities in the field, in which the importance of the work is evaluated. These can with advantage also be sollicited from non-European physicists.

EPS members who know of a qualified candidate are urged to submit a complete nomination to the Selection Committee, to arrive before 15 Sept. All information will be treated as strictly confidential, and although proposals will be acknowledged, there will be no further correspondence.

Nominations should be addressed to:

Selection Committee,

H-P Europhysics Prize

EPS, Nádor u. 7, H-1051 Budapest

P. Wyder

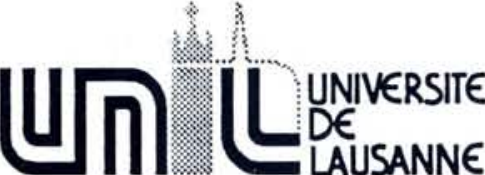

Notre Faculté des sciences met au concours deux postes de

\section{Professeur ordinaire (full professor)}

en physique expérimentale de la matière condensée

Entrée en fonction: octobre 1992 ou à convenir.

Participation à l'enseignement de I'Institut de physique expérimentale en physique générale et physique du solide. Infrastructure de recherche à disposition Icryogénie, production de hauts champs magnétiques, métallurgie, centre de microanalysel.

Les candidatures (avec c. v. et liste de publications) doivent parvenir avant le 31 août 1991 à M. J.-C. Bünzli, Doyen de la Faculté des Sciences, Collège propédeutique, $\mathrm{CH}-1015$ Lausanne. Renseignements complémentaires: $M$. G. Wanders, Section de physique, $\mathrm{CH} 1015$ Lausanne, tél. 021/692 23 84. Soucieuse de promouvoir l'accès des femmes à la carrière acadé mique, l'Université encourage les candidatures féminines.

\section{CALL FOR NOMINATIONS}

\section{Sections of the Condensed Matter Division}

Elections to the Committees responsible for the Sections of the Condensed Matter Division will be held by mail as soon as the preparations are complete.

Below is a provisional list of candidates prepared by the Chairman of the Division in consultation with the present Committee Chairmen. Individual Ordinary Members who are Section members and National Societies, Category $4 \mathrm{~b}$ ), are invited to make additional nominations. Those made by IOM's should be supported by at least six members.

Each Committee consists of six full members, elected for a term of three years, plus up to six co-opted members. The Sections then elect their own Chairmen and these serve on the Board of the Division. The maximum continuous period over which a Committee member may serve is six years.

In the lists that follow, the names of the Committee members elected at the last elections in 1987 are marked with an asterisk.
Liquids

*) S. Barocchi, Firenze

*) T. Dorfmüller, Bielefeld

J.E. Enderby, Bristol

*) J. Janik, Krakow

G. Nicolis, Bruxelles

*) M.G. Velarde, Madrid

Low Temperature

*) S. Erne, Berlin

G. Frossati, Leiden

*) J. Hook, Manchester

*) J.P. Laheurte, Nice V.V. Moshchalkov, Moscow

*) H.R. Ott, Zürich

*) G.L. Romani, Roma

Macromolecular Physics

*) D.C. Bassett, Reading U. Gedde, Stockholm

*) P.J. Lemstra, Eindhoven

*) B. Lotz, Strasbourg

*) E. Martuscelli, Naples G. Strobl, Freiburg i. Br.

Magnetism

J. Bessa-Sousa, Porto

*) I.A. Campbell, Orsay

*) J.A. Mydosh, Leiden H. Kirchmayr, Wien

*) P. Wachter, Zürich

W. Zinn, Jülich

\section{Metals}

*) F. Cyrot-Lackmann, Grenoble S.E. Giuliano, Messina

H.J. Güntherodt, Basel

*) G. Martin, Vitry-sur-Seine

*) M.S. Springford, Sussex

*) A. Zawadowski, Budapest

Semiconductors and Insulators

*) G. Martinez, Grenoble R. Nicholas, Oxford

*) M. Schultz, Erlangen

*) B. Velicky, Praha L. Vina, Madrid

*) D.L. Weaire, Dublin

Surfaces and Interfaces

*) V. Bortolani, Modena

*) S. Holloway, Liverpool

*) B. Kasemo, Göteborg

*) M. Landolt, Zürich

*) G. Lelay, Marseille

*) K.H. Rieder, Berlin

Nominations should arrive at the EPS Budapest Secretariat by the end of May 1991 at the latest.

\section{Physicist - Superconductivity}

A research scientist position is vacant in the Superconductivity Group at SINTEF Applied Physics Trondheim, Norway.

We seek a Ph.D. with 2-4 years postgraduate experience. The pre ferred field is experimental superhigh $\mathrm{T}_{c}$. Other relevant fields are magnetic materials, elastic measurements, SQUID-physics and-technology.

The Superconductivity Group con $6 \mathrm{Ph}$.D. students and some underconductivity research, especially sists of 1 professor, 2 post docs. graduates. We collaborate with leading groups in Europe, Japan and the USA.

The salary will be in a range starting from USD 45,000 , increasing with relevant experience.

Contact Professor K. Fossheim,

SINTEF Applied Physics

N-7034 Trondheim

NORWAY

Phone: $\begin{aligned} & +477593638, \\ & +477597041\end{aligned}$

Fax: $\quad+477593695$

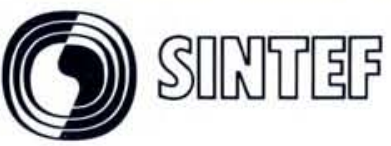

SINTEF - The Foundation for Scientific and Industrial Research at the Norwegian Institute of Technology. SINTEF is a leader in contract research for
industrial and non-industrial enterprises and public administration. It cooperates closely with the Norwegian Institute of Technology. SINTEF is the largest research organization in Norway, with 